Teaching \& Learning (2013), 7(3), 16-28

\title{
Teaching \& Learning about Humanitarian Law: Perspectives from Canadian Teachers
}

\author{
CATHERINE BAILLIE ABIDI \\ Mount Saint Vincent University \\ MARY JANE HARKINS \\ Mount Saint Vincent University
}

\begin{abstract}
Respect for human dignity and appreciation for diverse understandings are two quintessential elements of peaceful practices. Education focused on respect and the consequences of war, is essential for today's youth, given the global impact of war. International humanitarian law was established to promote respect during war, to protect civilians and those no longer fighting. Humanitarian law education can create space for critical consciousness, self-reflection, and active citizenship. This study explores Canadian teachers' experiences teaching and learning about social justice, war, and conflict, through the educational resource, Exploring Humanitarian Law (EHL). The main findings include (1) the importance of helping students to discover meaningful, real world connections, (2) teachers' perceptions about the relevancy of international humanitarian law education, (3) tools for engaging all students, and (4) the constraints and challenges of implementing humanitarian law curriculum. Recommendations for practice and future areas for research are suggested.
\end{abstract}

\section{Introduction}

In the face of major challenges such as climate change, conflicts and violence, migration and urbanization, young people everywhere are showing that they want to be part of the solution... Youth around the world are exploring humanitarian law enabling them, as tomorrow's leaders, to take decisions preventing unnecessary suffering in times of armed conflict and other situations of violence. Today, young people are already making a profound difference in the lives of vulnerable people. (Kellenberger \& Konoé, 2012)

Respect lies at the heart of humanity. Respect for human dignity and appreciation for diverse understandings are two quintessential elements of peaceful practices. Given the global impact of war and conflict, it is essential for today's youth to fully embrace respect for self and others, and to learn new ways for conflict resolution (Hinterlietner, 2010; LeRoux, 2001). 
Humanitarian law education can create space for critical consciousness, self-reflection, and active citizenship (Baillie Abidi \& Harkins, 2012; Tawil, 2000). Education focused on humanity and humanitarian action is relevant, valuable, and necessary (Baillie Abidi \& Harkins, 2012; Hinterlietner, 2010; LeRoux, 2001; UNESCO, 1995).

This paper explores Canadian teachers' experiences in teaching and learning about social justice, war, and conflict, through the educational resource, Exploring Humanitarian Law (EHL). EHL was designed by the International Committee of the Red Cross, to engage youth in discussions about respect and humanity, to increase understanding of international humanitarian law and the consequences of war, and to promote humanitarian action.

Given the importance of humanitarian and global education, and its relationship to youth citizenship, it is important to explore teachers' perspectives about teaching humanitarian and social justice-based curriculum. Teachers constantly make decisions about curriculum implementation, and are a key influence in the social and academic aspects of the classroom (Hargreaves, 2003). It is therefore important to explore how teachers reflect on their teaching practices in the area of humanitarian issues. The purpose of this study was to increase our understanding of teachers' experiences learning and teaching about war, conflict, and international humanitarian law.

\section{Teaching Humanitarian and Global Education}

International Humanitarian Law (IHL) education focuses on respect for human dignity, and emphasizes the rules which restrict the means and methods of war (Henckaerts \& DoswaldBeck, 2005; Sassoli \& Bouvier, 1999). The main goal of IHL education is to reduce suffering caused by armed conflict (Henckaerts \& Doswald-Beck, 2005; Sassoli \& Bouvier, 1999). Considering that the Geneva Conventions of 1949, the main treaties informing IHL, are universally ratified, all States have an obligation to promote the principles of IHL (Kalshoven \& Zegveld, 2011). As contemporary conflict transforms and is impacted by globalization, the knowledge of and respect for IHL becomes even more essential, as a tool to protect people affected by armed conflict.

Globalization is resulting in growing inequity and increased conflict (World Health Organization, 2002). Since World War II, close to 200 armed conflicts have occurred (World Health Organization, 2002), and more than ever, they are impacting civilians not engaged in the 
fighting (Fresard, 2004; Henckaerts, 2005). War and armed conflict result in loss of life and loss of community (Greenberg Research, 1999), and are directly or indirectly affecting people in all regions of the world. In recognition of the increasing impact of conflict, global and humanitarian education on intrapersonal, interpersonal, and international violence is essential.

Global education, which includes education focused on global violence and conflict, has diverse interpretations (LeRoux, 2001; Pike, 2000). For teachers who feel a responsibility to prepare students to become informed, critical citizens in a diverse society, "it is not fully clear as to what kind of globalization educators are urged to prepare their students for" (Agbaria, 2011, p. 58). Most research on global issues stems from the West, and focuses on cultural diversity and economics, to the exclusion of other issues, including international conflict and human rights (Agbaria, 2011; Andreotti, 2011; Parmentor, 2011). "The difficulties schools face are compounded by another growing perception that now they must not only provide skills for the information age but also prepare students for effective citizenship in multicultural societies battling poverty and inequality, escalating social problems, and the breakdown of civility" (Agbaria, 2011, p. 63).

Similar to global education, the concept of global citizenship is culturally informed and shaped by experience, principles, and norms (Gaventa \& Tandon, 2010; Merryfield, 2002; Morais \& Ogden, 2011). Although many educational institutions reference goals aspiring for the achievement of global citizenship, the skills and values of a global citizen are unclear and controversial (Camicia \& Franklin, 2011; Gaventa \& Mayo, 2010). Defining global citizenship is a challenging endeavour; however, a few key principles are frequently cited in the literature, including the importance of social responsibility, an increased understanding and awareness of cultures and norms, as well as increased civic participation (Morais \& Ogden, 2011).

Within global education and the fostering of global citizenship, many agree that the use of diverse strategies to connect with students' different ways of knowing, is essential as a way to engage students in learning about global and social issues (Baillie Abidi \& Harkins, 2012; Byford, Lennon, \& Russell, 2009). Peer dialogue about controversial issues in a safe environment, is key to engendering a climate of trust, and an essential element to developing a culture of peace (Byford, Lennon, \& Russell, 2009; O’Kane, Feinstein, \& Giertsen, 2009). Experiential learning, reflection, participant-centred education, and safe learning spaces, are key aspects of education rooted in peace building and violence prevention (Nazzari, McAdams, \& 
Roy, 2005). The link between education and action is a vital element of conflict transformation (Frantzi, 2004; Gaudelli \& Fernekes, 2004).

\section{Research Design}

A qualitative research design was selected to allow for teachers' perceptions of their experiences teaching and learning about humanitarian law, to become the focal point of the analysis. Qualitative research paradigms emphasize the social construction of learning, enabling the voices of the participants to be the primary focus (Creswell, 2007; Merriam, 2009). As the purpose of this study was to construct meaning from the perceptions of classroom teachers who were teaching international humanitarian issues, a social constructivist theoretical framework was used. This approach is based on the belief that knowledge is constructed, and learning must be contextualized within social contexts (Dewey, 1938; Vygotsky, 1978). The main research questions were: how do teachers describe their experiences teaching modules from the educational resource, Exploring Humanitarian Law; and what are the influences that impact on their teaching about international humanitarian issues?

Invitations were sent to ten classroom teachers who were teaching modules from the Exploring Humanitarian Law (EHL) resource in secondary schools in Eastern Canada. EHL is an online resource (www.ehl.icrc.org) comprised of over thirty-five hours of educational curriculum in the area of conflict-related humanitarian issues. The opening sections encourage an exploration of perceptions about humanity, war, otherness, and dignity, followed by a focus on the role of bystanders and humanitarian action in situations of conflict. Learners are guided using diverse strategies to explore the complexity of conflict in the twenty-first century, by learning and applying the rules of war, examining the international justice system, and the consequences of war. Throughout EHL, learners are encouraged to critically examine responsibility, actions, consequences, and diverse perspectives, while considering options for humanitarian action.

All the teachers had previously received a three-day in-service on Exploring Humanitarian Law. These in-services which were similar in content, had been delivered over the past several years. There was at least one teacher invited from each of the regional school boards in the Province. This meant that there was geographical representation, as well as representation from teachers who had attended different in-service sessions. 
Nine teachers agreed to participate in the study, six females and three males. Two of the participants were teaching in urban high schools, and seven in high schools in rural areas. Among the participants there was an average of 20 years of teaching experience, ranging from 5 to 32 years. They taught a total of 24 different subjects at the high school level, with Global History 12 being the most common. Among the nine participants, EHL had been used in 76 classes, involving a total of 2,130 youth in grades nine to twelve.

All of the teachers who agreed to participate in this study were invited to complete a short demographic questionnaire, as well as participate in a focus group. For the focus group session, the researchers developed a set of open-ended, guiding questions, which were distributed to the participants. The recorded session was approximately 80 minutes, and was conducted in a local university. A focus group was utilized because, as Morgan (1997) writes, group interactions can enhance the information and insights gleaned from guiding questions. This is an efficient approach, as it promotes in-depth discussions in a relatively short timeframe. Focus group discussions allow for new questions to emerge that can promote participants to explore the reasoning behind the what and how of participants' lived experiences. There are limitations however, as all information is based on self-reports, and there is a lack of observations in a natural setting (Morgan, 1997).

The conceptualization of the participants' responses was guided by the constant comparative content method, in which the data was transcribed and systematically coded. The constant comparative method involves a process of coding data and identifying categories. The initial coding is an open-ended, inductive process, in which key words or phrases are identified (Corbin \& Strauss, 2008; Lincoln \& Guba, 1985). Once the researchers had established interrater reliability in the coding, general patterns or categories were developed. As the data was analyzed, categories were compared with the codes of other categories, so that as many meanings as possible were identified. Embedded meanings and relationships began to emerge from the data, providing a better understanding of the relationships among the different codes within the categories. As patterns were identified among the categories, three key themes emerged from the data and served to highlight the critical, reflective thinking of the participants in the focus group. In the following section these themes will be explored and discussed, using excerpts from the data. 


\section{Findings \& Discussion}

This study explored Canadian teachers' experiences teaching and learning about social justice, war, and conflict through the educational resource, Exploring Humanitarian Law (EHL). The data was generated from a focus group with teachers using EHL in their classrooms. Three key themes emerged from the discussion: (a) Real World Connections; (b) Teaching for Social Change; and (c) Implementation: Supports and Challenges.

\section{Real World Connections}

The participants discussed many aspects of teaching and learning about war and conflict through the use of EHL; however, one theme repeatedly emerged in the discussions: the importance of connecting curriculum, and in particular global issues, to the real world. Time after time, the participants cited how teaching about current global challenges by engaging students with stories of real people, and often real young people, prompted a rich level of dialogue. One participant shared that "if you provide them [students] with information that is relevant to them that they can identify with, especially when you're working with child soldiers, they can see themselves in the eyes of these young children." Another participant stated that the methods and stories shared in EHL "took them out of the realm of their own experience and into the lives of somebody like them." As one participant shared, "they see that it [war] starts off from individuals, and maybe we could look at better ways of handling some of the conflicts we have in our own communities."

Although many tools within EHL were referenced as having created effective connections to the real world, a video highlighting the experiences of two young former child soldiers entitled I Don't Want To Go Back, was selected by all participants as having the most significant impact on their teaching and learning about conflict-related humanitarian issues. One participant stated that using a documentary video about youth who had experience with conflict, was a powerful tool to engage their students, "because it's just a real kid who just got out and he just wants to be in a normal... They look and go, oh my god, this is unbelievable...because it's not all hyped up like with Hollywood, like with Blood Diamond or anything. It's just a little kid you know, and then you see the commander." 
Viewing documentary film can be a powerful teaching strategy. As the resource is viewed by the students, it appeals to both their auditory and visual cognitive abilities. Marcus and Stoddard (2009) state that the combined use of images and audio of documentary films can be "powerful, provocative, and engaging" (p. 282). Follow-up discussions among students or between the teacher and students, have the potential to help students to understand the complexities of issues, to address affective reactions, to identify values, and to make sense of the producer's purpose in making the film (Marcus \& Stoddard, 2009).

\section{Teaching for Social Change}

Participants felt that EHL was a powerful strategy for preparing all youth for active global citizenship. These instructional approaches encourage the recognition of students' different ways of knowing, and the development of problem solving skills in a real world context, by providing a range of teaching strategies. The strategies range from problem solving, the use of photo collages, debate, drama, exploring actions and consequences, and the use of dilemmas. For example, in one module the students delve into a scenario of a combatant's dilemma and are encouraged to consider possible actions, as well as the consequences of each action. In another module, students learn about the consequences of war on civilians, by working with their classmates to design and build a refugee camp. The strategy emphasizes the complexity of humanitarian action in conflict, and the diversity of needs of displaced persons. These approaches to teaching can lead to increased opportunities for the active involvement of the students, and engagement in critical thinking and self reflection (Byford, Lennon, \& Russell, 2009).

The participants made the following observations with regard to inclusive student engagement:

It doesn't matter who the student is, the students become engaged, and that's what's most valuable for me.

The kit has a variety of resources, and that speaks to the different learning styles of students. So you have the video, you have the collage, you have the narratives, 
so it speaks to the interests of many different students. And I think that's what makes it even more powerful.

And we talked about the importance of citizenship too, and I think with this particular one, because they're so engaged, they're so much more likely to express themselves and give opinions, and give comments. Whereas, you get some students that will not participate, but will with this course because they all have an opinion, they know how they feel about it, so they're more likely to share.

The participants also discussed strategies they felt were effective for preparing their students for active citizenship. They focused on the importance of awareness and education, combined with skills for fostering deep reflection and participation in social issues. One participant described the importance for students to "make a connection between the lack of human rights, human dignity, and the way people behave." They described EHL as a tool that empowered students for action, by encouraging critical reflection on global issues, respect for diverse perspectives, and the promotion of action as agents of change. When dealing with controversial issues, it is important that the students be instructed in strategies on how to debate issues and to deal with differing opinions, so the classroom environment allows for diverse perspectives on controversial issues. The development of these skills is important for future, meaningful participation in a democratic society (Kuthe, 2011). The participants shared the following reflections on empowering student action:

It [EHL] gives the tools to the students to foster a greater understanding of the events, but also to understand that they are potential agents for change, and that they can put pressure on their governments if they see something that is not just.

It [EHL] gives them the ability to make greater sense of what they're reading in the newspapers, or what they're seeing on the television, hearing on the radio.

[EHL] gives them the opportunity to open their eyes, shed light, and also equip them. 


\section{New Implementation: Supports \& Challenges}

The first challenge teachers experience when implementing new curricula, is the need to gain a strong background of knowledge in the subjects being taught, especially when the topics are controversial (Kuthe, 2011). Participants described multiple features of EHL, with regard to developing their knowledge in the area of armed conflict and humanitarian law. They referenced the importance of the three in-service days they received from the Canadian Red Cross, which focused on humanitarian law, and practicing teaching with EHL modules. The participants also discussed the value of follow-up information and ongoing contact (e.g., the comprehensive website, the network of teachers using EHL, and background information provided to teachers). One participant in particular described the value of the background sections in EHL, sharing that:

often we get kits that are strategy-based, activity-based, but we don't have that background information, which can sometimes discourage a teacher from using that because they don't feel that they're properly equipped. But this is I mean, it's a package deal, it's an amazing package. It has everything from the teaching strategies to the background information, so it equips the teacher.

Despite the identified strengths of, and support for, teaching international humanitarian issues in the high school curriculum, the participants were also constrained and challenged when implementing EHL into their courses. All participants discussed time constraints as being the biggest barrier to EHL implementation. While teachers are experiencing a loss of preparation and planning time, and reduction in teaching supports, they are also facing many new requirements that infringe on their time, such as new curriculum and assessment requirements, high-stakes testing, and computerized documentation of curriculum outcomes. Hargreaves writes that the “overexamined professional life is producing an unexamined, unreflective one” (2003, p. 108). One participant expressed frustration with the current focus on numeracy and literacy, and shared that "we're so hell bent and concerned about, you know, are we graduating kids from grade 12 and can they write, and can they read, and what's their literacy and what's their numeracy skills like, that we kind of forgot the idea that you know, how are they as citizens? What are their values?" 


\section{Conclusion \& Recommendations for Practice and Future Research}

Although the number of participants in this study is small, qualitative research is not about numbers, but rather the experiences of the participants. This study highlights classroom teachers' perspectives on the importance of teaching social justice and conflict-related humanitarian issues. This study also draws attention to effective strategies for inclusive student engagement on international humanitarian issues, through the use of educational resources, such as EHL. Teaching EHL allows teachers to be innovative and creative, while fostering a sense of global citizenship. As one participant shared, "we encourage them...to be compassionate. And you know, we plant a seed and we never know where that seed's going to blossom.”

Learning and teaching about social justice and humanitarian issues encourages selfreflexive practice. The participants shared how teaching social justice-based curriculum requires a commitment to constant reflection and openness to change one's practice. One participant shared "I think the most important thing I learned is the material itself...it encouraged me to research it more and look for more resources and more material." Another participant shared "because of the resources we have out there, just honing in on one thing, it just becomes amazing...you could do it forever...I just get very enthusiastic about it.”

Reflective practice is also enhanced through on-going dialogue with colleagues (Baillie Abidi \& Harkins, 2012). Several strategies to support practice in the area of humanitarian issues education, includes the development of teacher support networks, both regionally and internationally; engaging in on-line asynchronous teacher networks, where content, methodology, and inclusive education can be discussed and shared; as well as participating in teacher professional development opportunities focused on social justice and humanitarian education (Baillie Abidi \& Harkins, 2012). Both the International Committee of the Red Cross (www.ehl.icrc.org) and the American Red Cross (www.ehl.redcross.org) provide space for teachers to dialogue and learn together, through strategy exchanges, discussing diverse or complex perspectives, and seeking support from legal experts in the area of international humanitarian law.

Future research focusing on the impact of learning about social justice, conflict-related humanitarian issues, and student action would be a valuable addition to the perceptions and experiences of classroom teachers. One participant shared how EHL "demonstrates once again this notion of change, how change takes time, but change is the result of people's action and 
going back to the bystander... I have students at the end of the cluster munitions or landmines, or child soldiers... their question is what can I do?" Further research is necessary to explore student action, and to validate the perceptions and experiences of youth with regard to war and conflict transformation (O'Kane, Feinstein, \& Giertsen, 2009). Recognizing that secondary school may be the location of the "last humanitarian course they ever take," it is important that we have a stronger sense of the knowledge, attitudes, and behaviours that students develop as a result of humanitarian law based education. In our increasingly complex and interconnected world, students are going to be more affected than ever by global events. Teachers willing to learn and teach about international humanitarian issues, are helping to prepare students to take an active role in our globalized society. As one participant expressed, "it's really important that our students at the high school level who will be going out in the larger world, be aware of these issues and maybe even work towards a way where they might be able to contribute... to do something to make it better."

Catherine Baillie Abidi is a Doctoral Candidate in Educational Studies at St. Francis Xavier University in Antigonish, Nova Scotia. Her research interests include migration and settlement; active citizenship; humanitarian law education; peace education; and lifelong learning.

Mary Jane Harkins is the Director of Teacher Education at Mount Saint Vincent University, Halifax, Nova Scotia. Her research interests include inclusive education, globalization and humanitarian issues, teacher education, and Aboriginal studies. Prior to coming to the Mount, Dr. Harkins was a Coordinator of Student Services in the Tri County Regional School Board, Yarmouth, NS.

\section{References}

Agbaria, A. (2011). The social studies education discourse community on globalization: Exploring the agenda of preparing citizens for the global age. Journal of Studies in International Education, 15(1), 57-74.

Andreotti, V. (2011). (Towards) decoloniality and diversality in global citizenship education. Globalisation, Societies and Education, 9(3-4), 381-397.

Baillie Abidi, C., \& Harkins, M. J. (2012). Canadian secondary social studies teachers \& humanitarian education: Promoting global citizenship among youth. Canadian Perspectives: Education Coast to Coast to Coast, 2, 1-28.

Byford, J., Lennon, S., \& Russell, W. (2009). Teaching controversial issues in the social studies: A research study of high school teachers. The Clearing House, 84(4), 165-170.

Camicia, S., \& Franklin, B. (2011). What type of global community and citizenship? Tangled discourses of neoliberalism and critical democracy in curriculum and its reform. Globalization, Societies, and Education, 9(3-4), 311-322. 
Corbin, J., \& Strauss, A. (2008). Basics of qualitative research: Techniques and procedures for developing grounded theory ( $3^{\text {rd }}$ ed.). Los Angeles, CA: Sage.

Creswell, J. (2007). Qualitative inquiry \& research design: Choosing among five approaches. Thousand Oaks, CA: Sage Publications.

Dewey, J. (1938). Experience and education. New York, NY: Macmillan.

Frantzi, K. K. (2004). Human rights education: The UN endeavor and the importance of childhood and intelligent sympathy. International Education Journal, 5(1), 1-8.

Fresard, J. J. (2004). The roots of behavior in war. Geneva, CH: International Committee of the Red Cross.

Gaudelli, W., \& Fernekes, W. (2004). Teaching about global human rights for global citizenship. The Social Studies, 95(1), 16-26.

Gaventa, J., \& Mayo, M. (2010). Spanning citizenship spaces through transnational coalitions: The global campaign for education. In J. Gaventa \& R. Tandon (Eds.), Globalizing citizens: New dynamics of inclusion and exclusion. London, UK: Zed Books Ltd.

Gaventa, J., \& Tandon, R. (2010). Citizen engagement in a globalizing world. In J. Gaventa \& R. Tandon (Eds.), Globalizing citizens: New dynamics of inclusion and exclusion. London, UK: Zed Books Ltd.

Glaser, B., \& Strauss, A. (1967). The discovery of grounded theory: Strategies for qualitative research. New York, NY: Aldine De Gruyther.

Greenberg Research Inc. (1999). The people on war report: ICRC worldwide consultation on the rules of war. Geneva, $\mathrm{CH}$ : ICRC.

Hargreaves, A. (2003). Teaching in the knowledge society: Education in the age of insecurity. New York, NY: Teachers College Press.

Henckaerts, J. M. (2005). Study on customary international humanitarian law: A contribution to the understanding and respect for the rule of law in armed conflict. International Review of the Red Cross, 87(857), 175-212.

Henckaerts, J. M., \& Doswald-Beck, L. (2005). Customary international humanitarian law (Vol 1: Rules). Cambridge, UK: Cambridge University Press.

Hinterlietner, N. (2010). Combating intolerance, exclusion and violence through holocaust education. Paris, FR: UNESCO.

Kalshoven, F., \& Zegveld, L. (2011). Constraints on the waging of war: An introduction to international humanitarian law. Cambridge, UK: Cambridge University Press.

Kellenberger, J., \& Konoé, T. (2012). Joint statement from the presidents of ICRC and IFRC [News Release]. Retrieved from http://www.icrc.org/eng/resources/documents/newsrelease/2012/red-cross-red-crescent-day-news-2012-05-08.htm

Kuthe, A. (2011). Teaching the war on terror: Tackling controversial issues in a New York City public high school. The Social Studies, 102(4), 160-163.

LeRoux, J. (2001). Re-examining global education's relevance beyond 2000. Research in Education, 65(May), 70-80.

Lincoln, Y., \& Guba, E. (1995). Naturalistic Inquiry. Newbury Park, CA: Sage.

Marcus, A. S., \& Stoddard, J. D. (2009). The inconvenient truth about teaching history with documentary film: Strategies for presenting multiple perspectives and teaching controversial issues. The Social Studies, 100(6), 279-284.

Merriam, S. (2009). Qualitative research: A guide to design and implementation. San Francisco, CA: Jossey-Bass. 
Merryfield, J. (2002). Learning citizenship. IDS Working Paper. Sussex, UK: Institute of Development Studies.

Morais, D. B., \& Ogden, A. C. (2011). Initial development and validation of the global citizenship scale. Journal of Studies in International Education, 15(5), 445.

Morgan, D. L. (1997). Focus groups as qualitative research. Thousand Oaks, CA: Sage.

Nazzari, V., McAdams, P., \& Roy, D. (2005). Using transformative learning as a model for human rights education: A case study of the Canadian Human Rights Foundations' international human rights training program. Intercultural Education, 16(2), 171-186.

O'Kane, C., Feinstein, C., \& Giertsen, A. (2009). Children and young people in post-conflict peacebuilding. In D. Nosworthy (Ed.), Seen, but not heard: Placing children and youth on the security governance agenda. Zurick, $\mathrm{CH}$ : Lit Verlag.

Parmentor, L. (2011). Power and place in the discourse of global citizenship education. Globalisation, Societies and Education, 9(3-4), 367-380.

Pike, G. (2000). A tapestry in the making: The strands of global education. In T. Goldstein \& D. Selby (Eds.), Weaving connections: Educating for peace, social and environmental justice. Toronto, ON: Sumach Press.

Sassoli, M., \& Bouvier, A. A. (1999). How does law protect in war? Cases, documents and teaching materials on contemporary practice in international humanitarian law. Geneva, CH: International Committee of the Red Cross.

Tawil, S. (2000). International humanitarian law and basic education. International Review of the Red Cross, 82(839), 581-599.

United Nations Education, Scientific, and Cultural Organization. (1995). Strategy on human rights 1996-2001. Paris, FR: UNESCO.

Vygotsky, L. S. (1978). Mind in society: The development of higher psychological processes. Cambridge, MA: Harvard University Press.

World Health Organization. (2002). World report on violence and health. Geneva, $\mathrm{CH}$ : World Health Organization. 